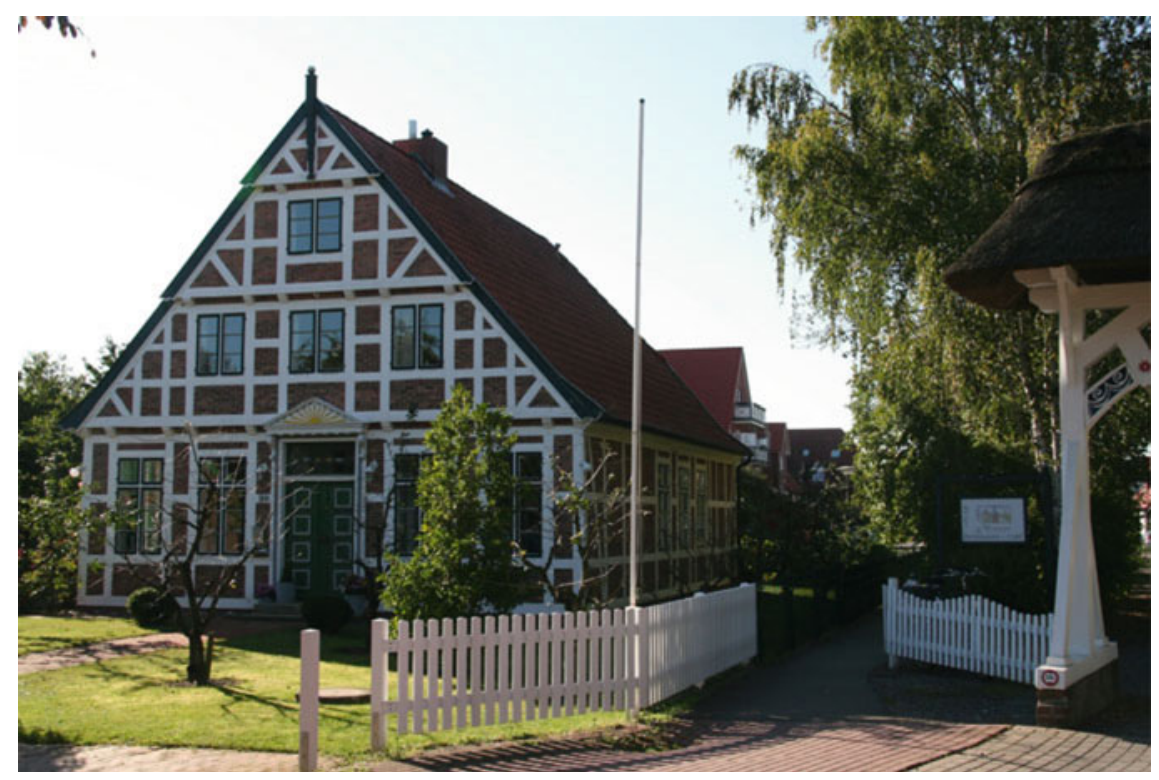

Dutch influence is evident in Holler colonies all over Europe, both in the construction of the land and in the built heritage, Alexandra Kruse, released under a Creative Commons Attribution 3.0 Unported License 


\title{
Chapter 7 \\ Holler Colonies and the Altes Land: \\ A Vivid Example of the Importance of European Intangible and Tangible Heritage
}

\author{
Alexandra Kruse and Bernd Paulowitz
}

Tell me what you pay attention to and I will tell you who you are. — José Ortega y Gasset

\begin{abstract}
The Holler colonies are settlements in European marsh and dyke landscapes created starting in the High Middle Ages through land reclamation by Dutch water engineers who had been hired by local leaders. Some Holler colonies were later abandoned; others remained. Surviving colonies, some of which remain and are largely intact, was often changed by later land reclamation processes (Renes and Piastra 2011: 24). Today, the remainders of these landscapes are visible proof of the intangible and tangible heritage of European economic and social history. These created landscapes - Holler landscapes — are easily recognized by their linear landscape structure and small parceling. Other characteristic features are hydraulic engineering structures, such as dykes, drainage systems, receiving waters, and the pumping stations used to clear the marshes of water and strip parceling, linear settlements, and infrastructure, houses and farms in a row, dykes, roads and byways, ditches, and channels. Holler colonies are a European landscape typology in several respects. First, they were the consequence of Dutch water engineers' large-scale knowledge transfer within Europe, are always built at the invitation of local leaders, and always encompass the diffusion of Dutch laws, traditions, production, and models of society. Second, they may be considered a European landscape type that defined European wetland areas along large rivers from the Middle Ages onwards. Their uniqueness is based on the techniques applied, the social processes involved, and their long duration.
\end{abstract}

Keywords Landscape history $\cdot$ Cultural heritage $\cdot$ Rural development Landscape resilience $\cdot$ People's identity $\cdot$ Landscape heritage

\footnotetext{
A. Kruse ( $\triangle)$

insitu World Heritage Consulting, Buc, France

e-mail: akruse@whconsult.eu

B. Paulowitz

Hamburg, Germany

(C) The Author(s) 2020

C. Hein (ed.), Adaptive Strategies for Water Heritage,

https://doi.org/10.1007/978-3-030-00268-8_7
} 


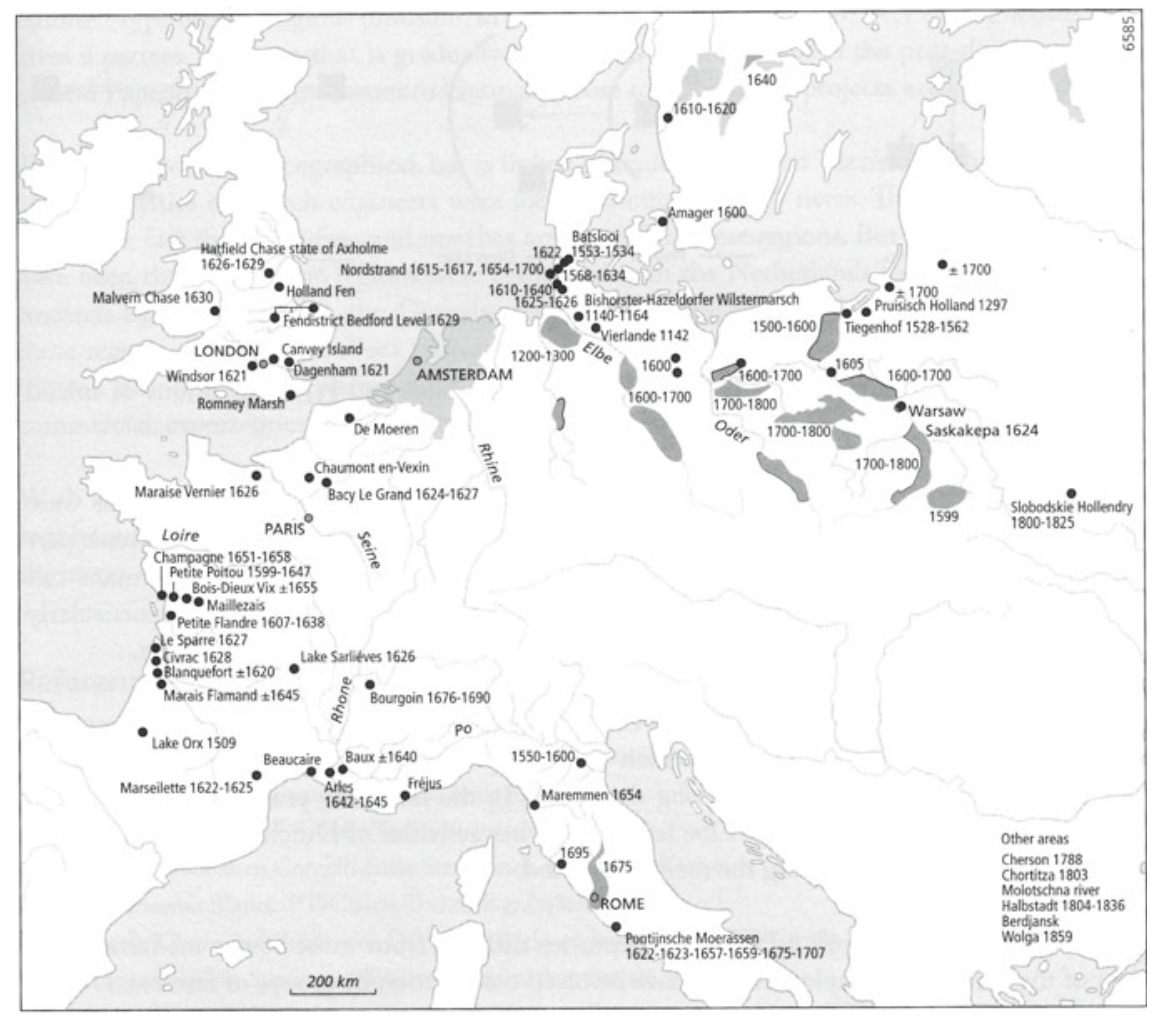

Fig. 1 Land reclamation and improvement measures carried out by the Dutch. Source Renes (2005: p. 27), based on Van Veen 1955: p. 52; released under a Creative Commons AttributionNonCommercial-NoDerivatives 4.0 International License

Holler colonies were early European settlements made possible by a distinctive style of land reclamation. (Renes 2005: 27f, Fig. 1) Techniques for cultivating the marsh and peat regions of the Dutch Lowlands (van der Linden 2000: 292) were first developed in the eleventh century. Dutch engineers spread these techniques to many other European countries (Hofmeister 2009; Renes 2005: 27ff) in a process of inner colonization or inner expansion, centrally steered migrations that revitalized abandoned and less populated areas, often closely linked to new parceling (Bartlet 1993). The name Holler colonies points to the people from the Low Countries, often called $\mathrm{Hol}$ länders, who reclaimed the land; it designates both this type of settlement and its surrounding landscape. This chapter details the characteristics of Holler Colonies and why they are distinctive in Europe.

This transfer of technology is the defining feature of Holler Colonies. Marsh and dyke land reclamation was planned and not random, not exactly the same everywhere but everywhere followed the same principles. In particular, this marsh and dyke reclamation exemplifies Cope cultivation. The term's origin in the Dutch and Low 


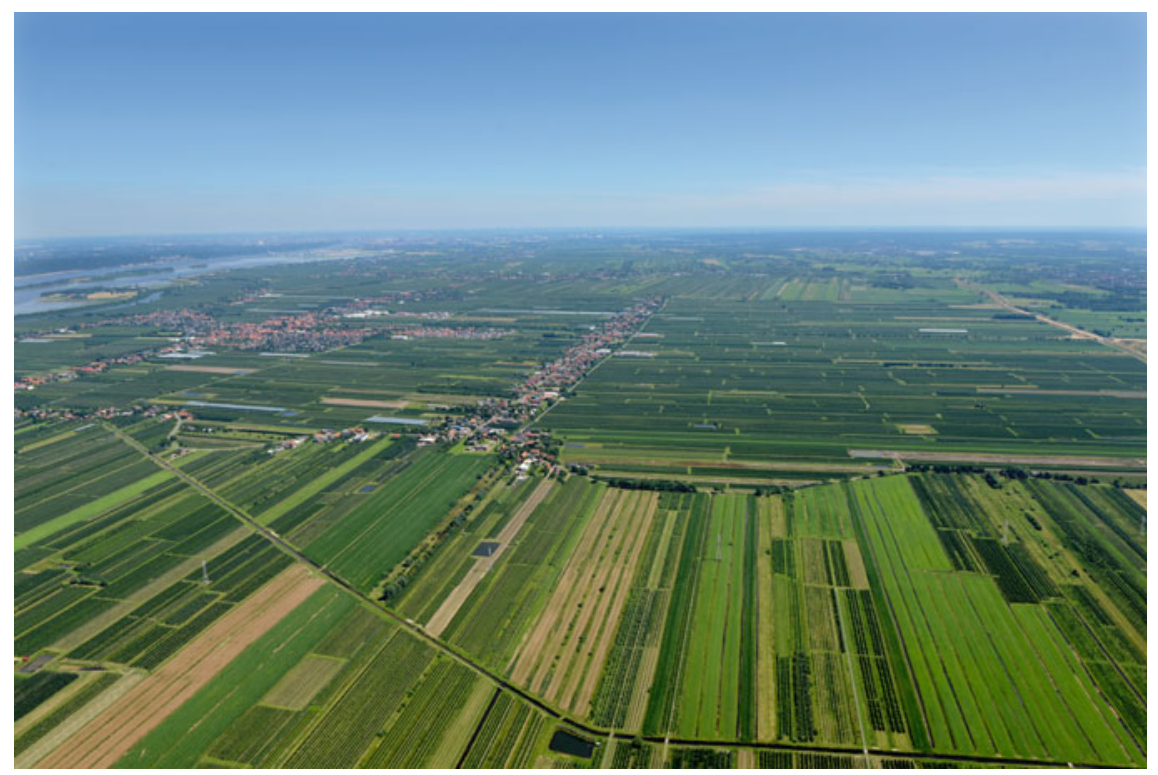

Fig. 2 Aerial view of the Altes Land shows the linear structure, very much related to the socalled mother landscapes in the Netherlands, e.g., Lopikerwaard, Wowbrugge, Teckop, which can be found again in other Holler Colonies, e.g., Malborg in Poland. Source With kind permission of Martin Elsen; released under a Creative Commons Attribution-NonCommercial-NoDerivatives 4.0 International License

German term "kopen", meaning "to buy," conveys that the Dutch settlers bought the land which they were asked to reclaim. This dynamic made their imported culture sustainable and distinguished the Holler colonies from other land reclamation areas.

The created landscapes - Holler landscapes — are easily recognized by their linear landscape structure and small parceling (Fig. 2). Other characteristic features are hydraulic engineering structures, such as dykes, drainage systems, receiving waters, and the pumping stations used to clear the marshes of water and strip parceling, linear settlements, and infrastructure, houses and farms in a row, dykes, roads and byways, ditches, and channels. Their linear structure is still visible all over Europe in the layout of fields, infrastructure (roads, paths, and ditches) and built heritage. The ensemble of features forms a unique and clearly identifiable landscape, still found in Germany (Kaup 2005), Poland (Chodyla 2005), Denmark (Stenak 2005), France (Toussaint 2005), and England (Williamson 2005). According to Lewandowski and Szewczyk (2008: 7), Holler settlements in Poland are particularly under pressure today and could well be inscribed on a list of endangered landscapes akin to the International Union for the Conservation of Nature's Red Book for Threatened Species (http:// www.iucnredlist.org/).

It may be useful to group or cluster these European landscapes as daughter landscapes of a Dutch mother landscape (Verein 2009: 109). Here, we concentrate on 
one of the best preserved examples of a daughter landscape, the Altes Land, literally "the Old Country," a region south of the Elbe River in Northern Germany, near the city of Hamburg. In examining the region, we are able to gain a short overview of the land-shaping process and demonstrate how a specific historic sociocultural development plays an essential part in our identity today. We also show how water, water infrastructure, and heritage have defined the identities and ways of life in these regions.

\section{The Low Countries as a Center of Innovation in Water Management}

The period of population growth of the tenth to the early fourteenth century was a demographic shift which triggered dramatic changes in land use; land reclamation and clearance in most parts of Europe accommodated the new populations (Renes 2010). This population increase was especially problematic for the Low Countries, where land for settlement and agriculture was scarce (Bartlett 1993) where large uninhabited fenlands, in most cases too wet for agricultural production, dominated the landscape. In response to these circumstances, the Dutch invented techniques to reclaim land from the marshes (Renes 2005: 13ff). With the invention of dykes in the tenth century, new areas became habitable and usable (Lebecq 1979:145). Soon, the Dutch developed large-scale drainage systems, including main channels and secondary ditches, to supplement the dykes. Another important new measure: a sustainable system for maintaining the dykes included a civic organization which was responsible for watching over and, if necessary, repairing them day or night at any time of year. These responsibilities were set out in contracts.

According to current knowledge, planned drainage commenced in the thirteenth century (Renes 2005: 27ff; Verein 2009: 27f). Almost immediately after its onset, Dutch technical know-how was in high demand by land owners and authorities elsewhere across Europe, who soon invited the Dutch engineers to come to help drain their lowlands. A later period of population growth, in the long sixteenth century (from 1450 to 1650), triggered another phase of reclamations. Especially in the Low Countries, this activity was characterized by an intensive use of existing arable and pasture lands (Renes 2010) and created less clearly visible and regionally distinct landscapes.

The Dutch hydraulic engineer Johan van Veen provides an overview of the history of Dutch reclamation activities throughout Europe in Fig. 1; although it dates from 1955, this is still the most complete map of its kind. Toussaint (2005: 121ff) has found that Dutch water engineers traveled to different areas, spreading knowledge of the embankment and its value throughout Europe, thus creating a unique continuity. The Center of Research on Holler Colonies in the Altes Land (founded in 2012) has started a deep investigation into the rationale for Dutch settlers' drainage measures and land reclamation technologies and of their societal consequences. 
The Dutch engineers and settlers brought other types of activities from Holland to the rest of Europe: They enriched communities with their often advanced knowledge and expertise in labor, new forms of social and political organization, commercial and economic networks, in addition to disseminating knowledge of how to drain and to maintain the wet landscapes which had been more or less unproductive (Lewandowski and Szewczyk 2008: 62f; Hofmeister 2009; Verein 2009: 15). Further contributions included legal traditions, capital investment, and, particularly in the Altes Land, place names. The material interventions were, from the time of origin, always closely linked to immaterial heritage. Water and heritage have now become a unity in these landscapes.

\section{Land Reclamation Process Under Dutch Influence and Introduction of Dutch Political and Social Models in the Altes Land}

The Altes Land, at $170 \mathrm{~km}^{2}$, approximately $30 \mathrm{~km}$ long, and, at its widest, $10 \mathrm{~km}$ wide, is limited by natural borders. The Elbe River lies in its northeast, a dense peatland of $0.5-3 \mathrm{~km}$ thickness in the southwest, and the Schwinge River in the northwest. The whole area of medieval land reclamation in the Altes Land $(=240$ hides $\sim 8000$ ha) has a distinctive legal history, leading not only to a recognizable landscape but also an independent mentality.

In 1113, Archbishop Frederick of Hamburg-Bremen invited a group of Dutch people to reclaim and cultivate the area along the Weser River. The Charta of 1113 ('Cope Contract'), a contract between the Archbishop of Bremen and the settlers that confirmed and specified the terms of the arrangement, shows that the Low Countries were reputed for their expertise in the reclamation of marshland. In it, settlers were guaranteed their "individual freedom and the ownership of the land reclaimed by them." (Hofmeister 1979). In other words, they were allowed to enjoy the same rights as in their home country (Hofmeister 1979). The Charta also granted them legal liberty, which led to a strong and distinctive cultural identity and tradition (Verein 2009: 15f). It was Priest Heinrich (cf. Fig. 3), born in Rijnsaterswoude in the Netherlands, working in Steinkirchen, who subsequently brought the Dutch water engineers to the area (Hofmeister 1979) of the Altes Land. The tithe of the Altes Land belonged at that time to the Archbishop Adalbero of Bremen and Hamburg (1123-1148), who was a key actor in shaping the region: He set up the governing structure in three districts (each called Meile, which is the German term for mile) that formed a legal, social, and economic unit until the first half of the nineteenth century. In 1140, Adalbero handed the tithe in Huttfleth (1st Meile) to the Hamburger cathedral chapter, and the one in Steinkirchen to the cloister Harsefeld. In 1148, he also added to Hamburg the tithe of Thitgerscoph (Hollern, 1st Meile). Adalbero's successor, the Archbishop Hartwig (1148-1168), who was also the duke of Stade, gave in 1149 to settlers in his territory the same rights as at the Weser and in Stade defining the legal 


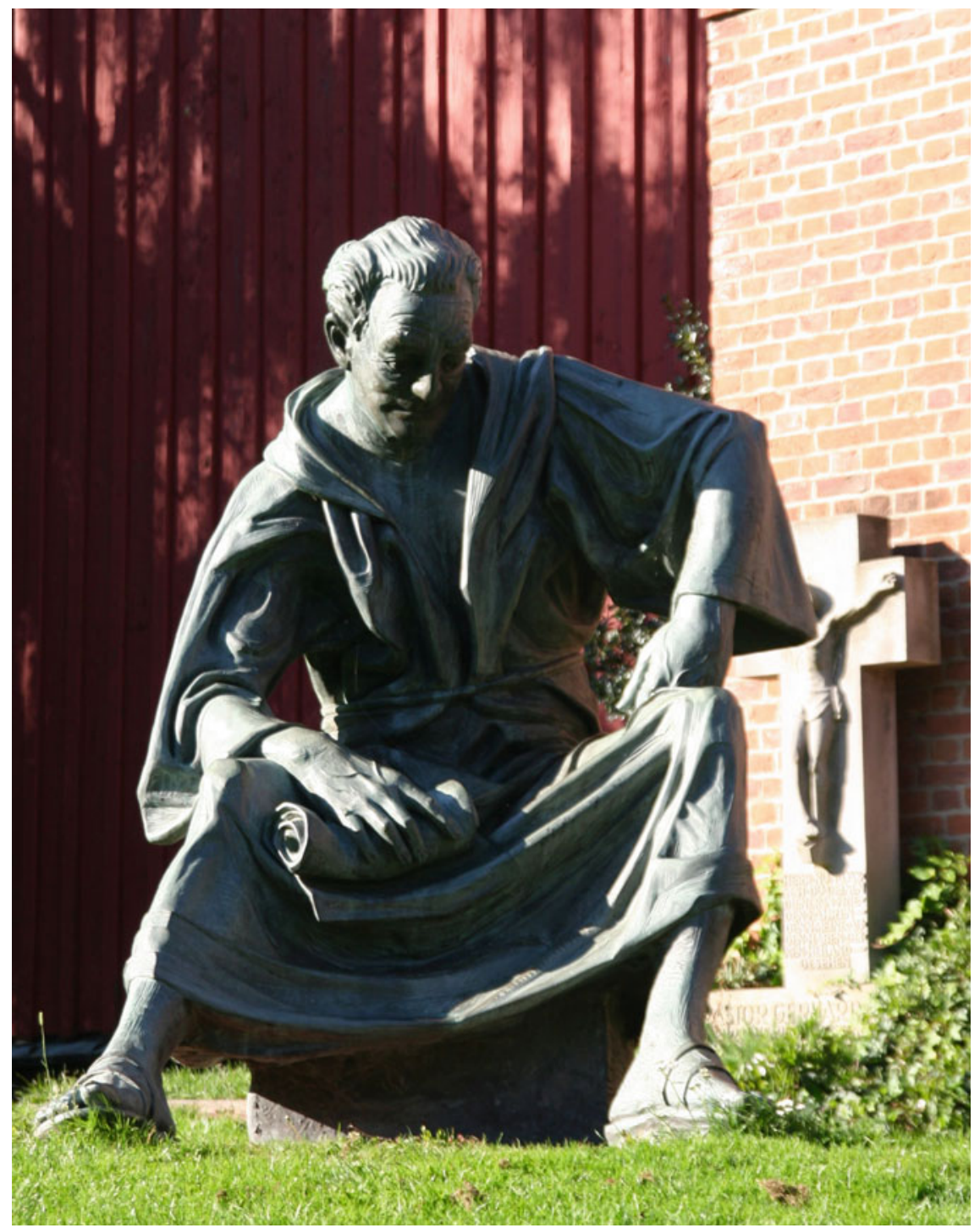

Fig. 3 Priest Heinrich symbolized the colonization process in the Altes Land from 1106. This 1992 bronze sculpture by Carsten Eggers stands in front of the church in Steinkirchen. Photograph Kruse (2011); released under a Creative Commons Attribution-NonCommercial-NoDerivatives 4.0 International License

framework for the colonists. While authority over the area was still often divided between the local dominant family and the Archbishopric of Bremen and Hamburg, the main colonization of the Altes Land ended in 1236, when Archbishop Gerhard of Lippe (1219-1258) gained full sovereignty over the second and third districts. 
As early as 1361, the territory had a specific seal, which was inscribed Sigillum Communitatis Veteris Terrae (i.e., the Seal of the Municipality of the Altes Land). That this occurred is important: it shows that the Altes Land was autonomous and therefore different from many other regions in central Europe at a very early stage. It was only after two events, the 1932 disbanding of the political district of Jork and the 1937 establishment of Greater Hamburg, that the unity of the Altes Land - which had held for many centuries - was suspended.

Thus, the Dutch model of society offered a great deal of freedom: political representation, sovereignty over local districts, land ownership, and local maintenance of the landscape. One result was a strong sense of citizenship. Such freedom and responsibility had been relatively unknown to local farmers in the High Middle Ages (Hofmeister 2009; Verein 2009: 15f) and were perhaps as a big a change for local political norms as reclamation was for the landscape.

\section{The Altes Land: Tangible and Intangible History and Heritage}

The transfer of technology and knowledge over the centuries was also critical to local identity. Fruit trees dominate the landscape and are, after landscape history, the second most important feature of local identity. Inhabitants began to cultivate fruit here (Fig. 4) very early: the first records are dated 1320, the year when Paul, son of Basilius Curia, sold to Johannes Tymbeke of Asse a yearly pension financed through his orchard (Verein 2009: 34). By roughly 1600, fruit had achieved a notable value. When the Archbishop of Bremen banned Hamburg beer from the Altes Land, the council of the city of Hamburg retaliated by banning cherries and other fruits from the Altes Land in the so-called cherry war. According to the rectification protocol (a legal provision on taxes) of 1657, the Altes Land had 743 fruit farms with 202 ha (Verein 2009). Fruit production gained even more importance after 1870, reaching its greatest importance in the 1960s.

Skilled crafts and trades developed in the seventeenth century in the Altes Land independently of the rights belonging to tradesperson offices in the neighboring cities of Stade and Buxtehude.

The design of private houses is of a particular high quality and refinement. It is clear that a great deal of money was spent on arranging their interiors (cf. Fig. 5). Pieces of regionally distinctive Altländer furniture are often still found in private houses and are on display in the Museum in Jork (Verein 2009). These include suitcase chests, settles, chairs, and the Hamburg Schapp, a distinctive baroque hall closet. These furniture pieces illustrate the durability of the Altländer society (Verein 2009).

The technical and cultural achievements of drainage, irrigation, and land reclamation, a highlight in European internal colonization processes, are still visible in the landscape, while the intangible heritage has often been lost. As one would expect, 


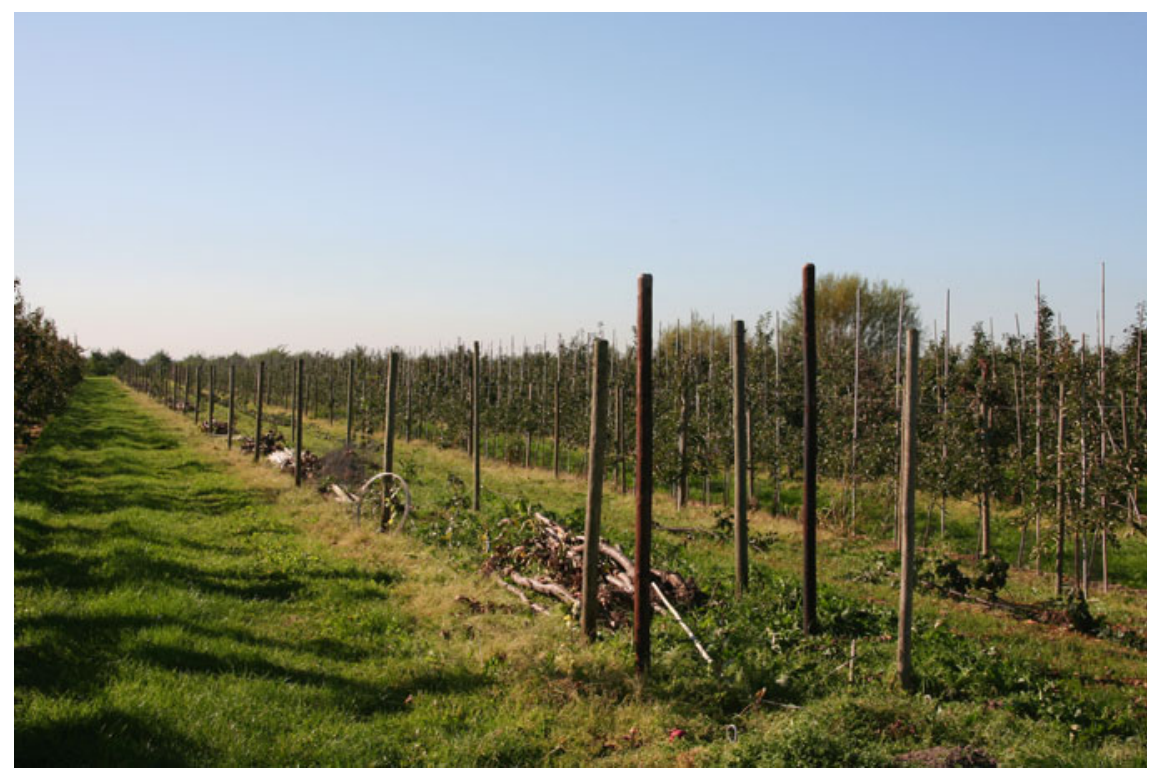

Fig. 4 Fruit plantations still follow the medieval plots. Source Kruse (2011); released under a Creative Commons Attribution-NonCommercial-NoDerivatives 4.0 International License

each of the Holler landscapes, whether in France, Poland or elsewhere, now look somewhat different from each other. Some of them, in particular in regions with a high self-administration, like Germany, retain many of the original cultural, social, and technical features, while others, where a strong national administration dominated politics, like France, retain only the distinctive landscape structure. In most places, later practices of land forming (like combining fields) overwrote the medieval patterns, either due to new societal needs (infrastructure) and or because of the modernization of land use and therefore the creation of larger plot units. We find as well the opposite phenomena, which mean that land was abandoned due to a lack of performance and/or productivity. The latter fact applies especially for Holler Colonies in Poland.

The very visible linear structures, the canal, ditch, and dyke system, as well as the social organization in the Altes Land have survived mainly because natural conditions made a different, more profitable use impossible. The Altes Land stands out today as best preserved example of the historic diffusion process originating in the "Low Countries," more so than in any other European area and even more recognizable than in the current-day Netherlands. As a result, we find a stunning integrity in this regional structure on a fairly large scale.

Finally, yet importantly, another feature of cultural and historic significance survives today: Continuous historical records and a well-kept archive. This too differentiates the Altes Land from the other landscapes where people from the Low Countries settled. Indeed, much of the research on Holler colonies in Europe originates here. 


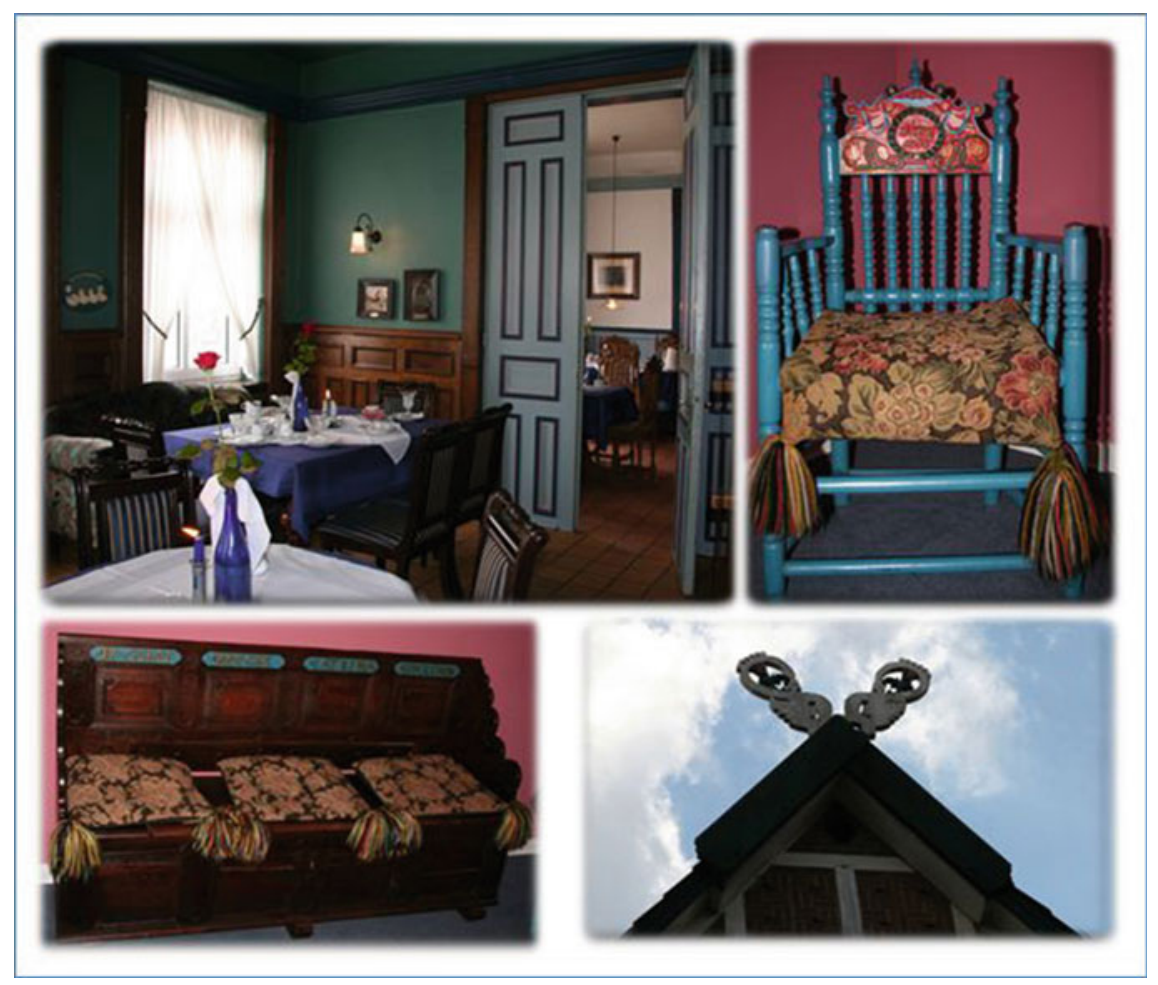

Fig. 5 Precious and colorful worked wooden furniture and interior decoration of the houses as well as symbols and figures at the roof tops are material proof of wealth and proudness of the Altländer people. All photographs taken by Alexandra Kruse; released under a Creative Commons Attribution-NonCommercial-NoDerivatives 4.0 International License

\section{Landscape, Identity, and Development in the Holler Colonies-Based on the Findings in the Altes Land}

In the Holler landscapes, landscape identity is not only geographic, but also very strongly social. The concept of landscape identity can be explained by the help of the so-called Swiss landscapes. These are wide and hilly landscapes appreciated highly since romanticism. Swiss landscapes are a kind of master landscape (idealtypische Landschaft), and therefore the terminology is used for similar landscapes in foreign countries, for example, Saxonian Swiss or Holsteinisch Switzerland in Germany. One may speak of an early marketing trick. However, the Swiss landscape model is primarily based on geographical features.

Holler colonies owe their distinctive character as ongoing cultural landscapes to the interactions between humans and nature, with a strong awareness and appreciation of traditional costumes and customs, buildings and architecture, dances, and dialect. Recently we find, for example, the costumes of the "blossoms queen (Blütenkönigin)" 


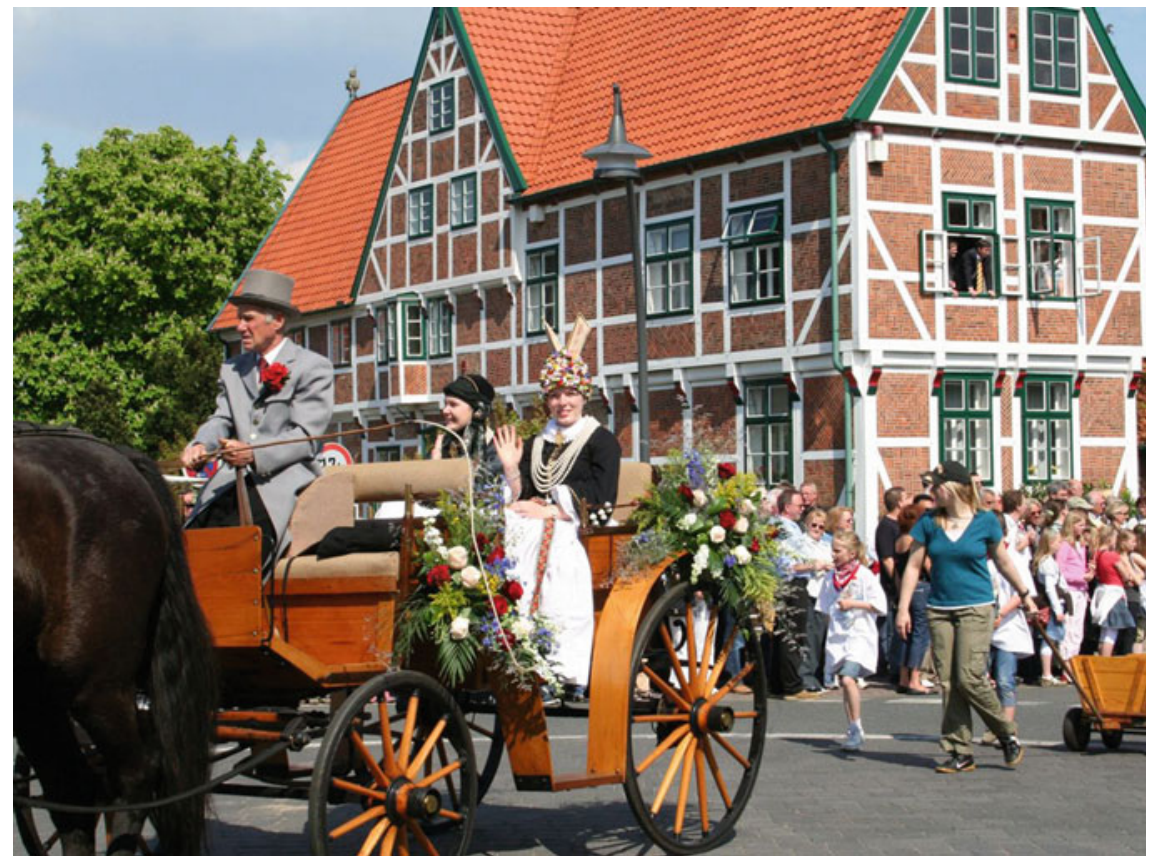

Fig. 6 Every year the blossom festival celebrates the fruit production; it is a magnet for thousands of tourists. The photograph shows the blossom queen with her maid in traditional costumes. Photograph with kind permission of the Association for the Recognition of the Altes Land as UNESCO World Heritage e.V.; released under a Creative Commons Attribution-NonCommercialNoDerivatives 4.0 International License

(cf. Fig. 6) and traditional wedding dress. Female tourist guides wear special outfits based on traditional dresses but newly designed and reintroduced.

Agricultural cultivation and other land use have fostered an anthropogenic designed landscape. The orchards were created on narrow marsh hides, so-called beds, delimited by parallel dykes (cf. Fig. 4). Other artificial elements of paramount importance to the cultural landscape include (see Fig. 7):

- the Altländer farms and courtyards

- the linear-shaped settlements

- medieval roads and trails

- the long strip parceling

- the number of bettors and straight drainage ditches, which underscore the overall linear structure.

The Altes Land has a long history of the peaceful settlement of foreigners of different origins, whose cultural, human, and societal impact is felt to this day. Findings from the Stone and Bronze Ages prove early settlement; from 200 AD Saxons came and settled only in the higher, dry areas (Hofmeister 1979). No fights or conflicts 

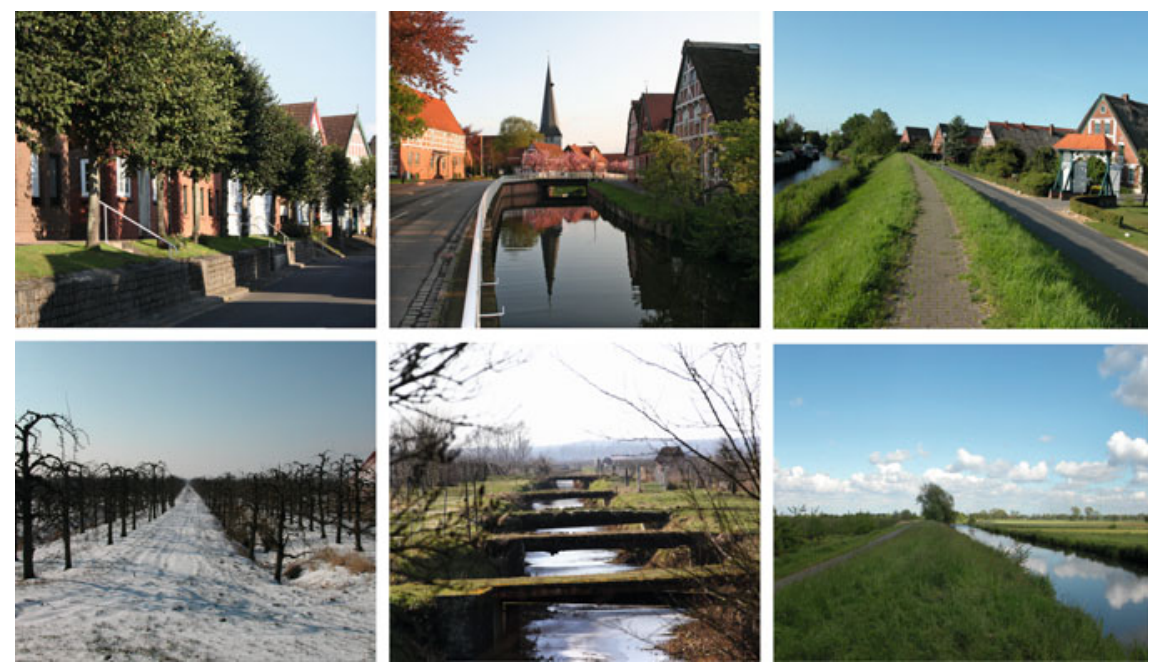

Fig. 7 Linear structures and elements form the landscape of a Holler colony, as here in the Altes Land. (From upper left to lower right: Estebrügge, Zesterfleth in Borstel, Deichhufendorf Mittelnkirchen Ort; bed-ditch structure in the orchards, Neuenschleusener Wettern, back dyke (Hinterdeich) at the Landwettern in Moorende. Photographs Silvia Hotopp-Prigge and Andrea Rachow, provided by the Association for the recognition of the Altes Land as UNESCO World Heritage e.V.); released under a Creative Commons Attribution-NonCommercial-NoDerivatives 4.0 International License

between the settlers originating from Saxony and the new ones from the Low Countries are recorded. The exchange and communication with the Dutch originating areas is still apparent and lived. This exchange was and is not only limited to landscape aspects but also is particularly rich and to be found in ideas and traditions. The strong link between the originating and colonized landscape was in earlier times organized through the church (church records of the seventeenth-century bear witness) and has been taken up since by cultural associations (Raap 2010).

\section{Dutch Society Models as Driving Force for Development}

As we have seen, one of the outstanding features of this cultural landscape was and is the freedom and self-determination of the citizens, an imported Dutch model. This idea of freedom led to many of the other characteristic features of the Altes Land. One is that women always held a very strong position here. For example, neither party to a jointly composed will could unilaterally change the text to the detriment of the other (Verein 2009). Women also had the right of succession. This is one reason why we find farms that are in the possession of the same family-undivided-since the 
fifteenth century, leading to a strong historical consciousness and social and regional cohesion (Verein 2009: 28f).

The social system established in the fourteenth century-with independent selfdetermination, regional auto-administration, and representatives_-also formed the preconditions for a flourishing economy.

Popular traditions and a distinctive dialect, still taught to children today, are sound evidence of a strong traditional cultural identity. This traditional identification made it possible for people to self-organize in cooperatives in order to carry out the necessary works and construction of the dykes (Hofmeister 2009). Citizens rather than politicians took responsibility for that work.

On a different scale, the development of larger rural municipalities as sustainable local cooperatives in parishes or peasantries with regional councils, a representative system, goes back to the eleventh and twelfth century; it was first observed in the Frisian populated coastal region and in Dithmarschen (Schleswig-Holstein). This political and social model, including its terminology, was soon to be found as well in the Dutch settled areas along the River Weser. One has to particularly highlight the separation of jurisdiction and administration that developed with the establishment of administrative sectors (Hauptmannschaften) in the fourteenth century; it preceded similar systems in central Europe of the nineteenth century. This autonomous administrative and judicial organization remained more or less intact in the Altes Land until the late nineteenth century. In short, as Verein (2009: 28f) wrote, "Since the fifteenth century, courts have remained the undivided property of one family for generations. Ownership structures, topography, rule-based conditions, contractual arrangements, and legal relations shaped the daily lives of people in the Altes Land in a special way over the past centuries."

\section{Current Status of the Landscape and Challenges to European Heritage}

Today, a variety of changes threaten the Altes Land. Due to its geographical proximity to Hamburg, the second largest town in Germany, there is a pressure from urban development, including the demand for industrial land use by the city and port of Hamburg. The shipping industry and other means of transportation have affected land use along the river Elbe, as well as the ground-water level. There is a proposal to further deepen the Elbe. The effects of that change on the marshlands and cultural landscape are yet unclear, but it will certainly change the soil conditions and therefore microclimates and agriculture. Ditches and canals risk drying out, which will not only affect biodiversity but also will make water-regulating features like locks and bridges obsolete-possibly even the former water bodies themselves. Further construction is a new physical, social, and cultural problem, constantly reducing the open area of the Altes Land, especially the farmland. Recent construction has included a new 
highway along the border between the Altes Land and higher elevations (Geest), and new industrial, commercial, and housing developments.

The Altes Land now belongs to two different Federal States, or Länder. The difference in development pressure is visible: The part belonging to the Federal State of Lower Saxony still retains the historically evolved landscape and historic features while the part belonging to the Federal State of Hamburg is undergoing constant change. In particular, the construction of the deep sea harbor and the resulting artificial hills of the dugout material altered the topography and therefore the visible integrity of the land. Similarly, the huge industrial development by the airplane builder Airbus destroyed parts of the historic landscape.

Another threat comes from outside. As mentioned earlier, the local agriculture is based on fruit production, mainly apples (in $200788.1 \%$ ), followed by cherries, pears, and plums (Verein 2009: 40). This system is under pressure from large-scale production all over the world that does not face the same environmental and topographic restrictions as we find here. It is also under pressure also from constantly renewed EU-regulations, which often do not take into account small-scale production when targeting production methods.

Several new environmental regulations restrict possibilities in regionally and topographically specific contexts. In the past, the farmers of the Altes Land always had to find a way to adapt their production methods to the traditional water management of dykes and ditches, and to fit their fields into the historical parceling. The traditional average distance between two ditches in the Altes Land measures 16-20 m. But the European Water Framework Regulation demands 5-m distance from a water body (in each direction) when using chemicals (European Commission 2000a), putting half the arable land out of production and leaving only a strip of 6-10 $\mathrm{m}$ for production-too small to be profitable. Not so long ago, many farmers addressed this problem by sealing the ditches, a lasting negative change not only in the established water management, but also, and this is even more important for our discussion, in the cultural landscape. An internal transformation process is underway, favoring high-quality and organic-based production, thus actually fostering preservation of both immaterial and material heritage. Organic agriculture would be a way for farmers in the Altes Land to follow regulations while keeping farming as a main income source, maintaining and reinforcing the historic cultural landscape, preserving traditions, and making the most of historic water management. Finding this balance might be the most important challenge facing the Altes Land.

Today, $4.1 \%$ of the farmers in the administration district of Stade, in which the Altes Land is located, produce under ecological farming labels (Kompetenzzentrum Ökolandbau 2017). The European Commission EIP-AGRI, a "Special area Altes Land" Operational Group financed by the EU rural development policy, not only looked specifically at organic farming but also found that some conventional processes and machinery are transferable to organic production. It will adapt a number of technologies so that all fruit farmers can apply them, bringing together organic and non-organic farmers as well as a number of research and advisory centers.

In both organic and conventional farming, avoiding spray drift when applying plant protection products helps to reduce adverse effects on the environment. The 
Operational Group is testing tunnel-application spraying systems. Vertical anti-drift nets are also being tested: Farmers set up these dense, 4-m-high insect nets around the orchards to catch a substantial part of spray drift (European Commission 2018). These programs might just the stimuli that Altländer agricultural sector needs to gain economic competitiveness while preserving its cultural heritage.

\section{Heritage, Region-Building, and the Future of the Altes Land}

A local group of citizens, the Association for the Recognition of the Altes Land as UNESCO World Heritage e.V." (Verein 2009), has been working since the beginning of this millennium to protect the historic landscape. At the beginning, its goal was to nominate the Holler Colony to UNESCO as a candidate for the World Heritage List. The group met local resistance, in particular, from farmers who feared the status would bring new restrictions. They pointed out their bad experience with environmental protection regulations, especially Natura 2000, a Europe-wide conservation network. (European Commission 2000b) The citizens' association had to become much more professional and enduring, capitalizing on growing awareness of UNESCO World Heritage and its status as an income source for many municipalities and state governments. The people from the Altes Land appropriated the idea that sustainable economic progress can also foster sustainable protection of their heritage. The association became expert in many planning issues and political debates, even as the concept of World Heritage itself evolved into a vehicle for regional development.

Today, the World Heritage nomination goal plays an important role in the local discussion of how to develop the Altes Land into a living area marked by high quality and prospects. Therefore, the goal is part of a new landscape plan (Samtgemeinde Lühe 2017). The farmers are correct that protection status would impose some limitations or even obligations on them, for example, requiring them to keep historic ditches intact. On the other hand, they could realize that it could help safeguard the Altes Lands as a high-quality agricultural production region and as a tourist destination (tourism is the second largest income sector in the region).

The local reflection and participation process that the Association has fostered over the last 15 years fits very well with the whole concept of the World Heritage Convention. In some ways, this road to World Heritage is more important than the status itself. Indeed, the citizens' initiative uses the World Heritage goal to work for a common future of the region.

The association members have organized many campaigns to raise local, regional, and global awareness of the history of the region and the unique historic cultural landscape that is a Holler colony. It organized several national and international symposia and exhibitions for locals and visitors as well as the national and international scientific community. Although not without encountering difficulties and negotiating continuous discussions, the association succeeded in getting farmers, municipalities, tourist organizations, and the general public behind the common goal. 


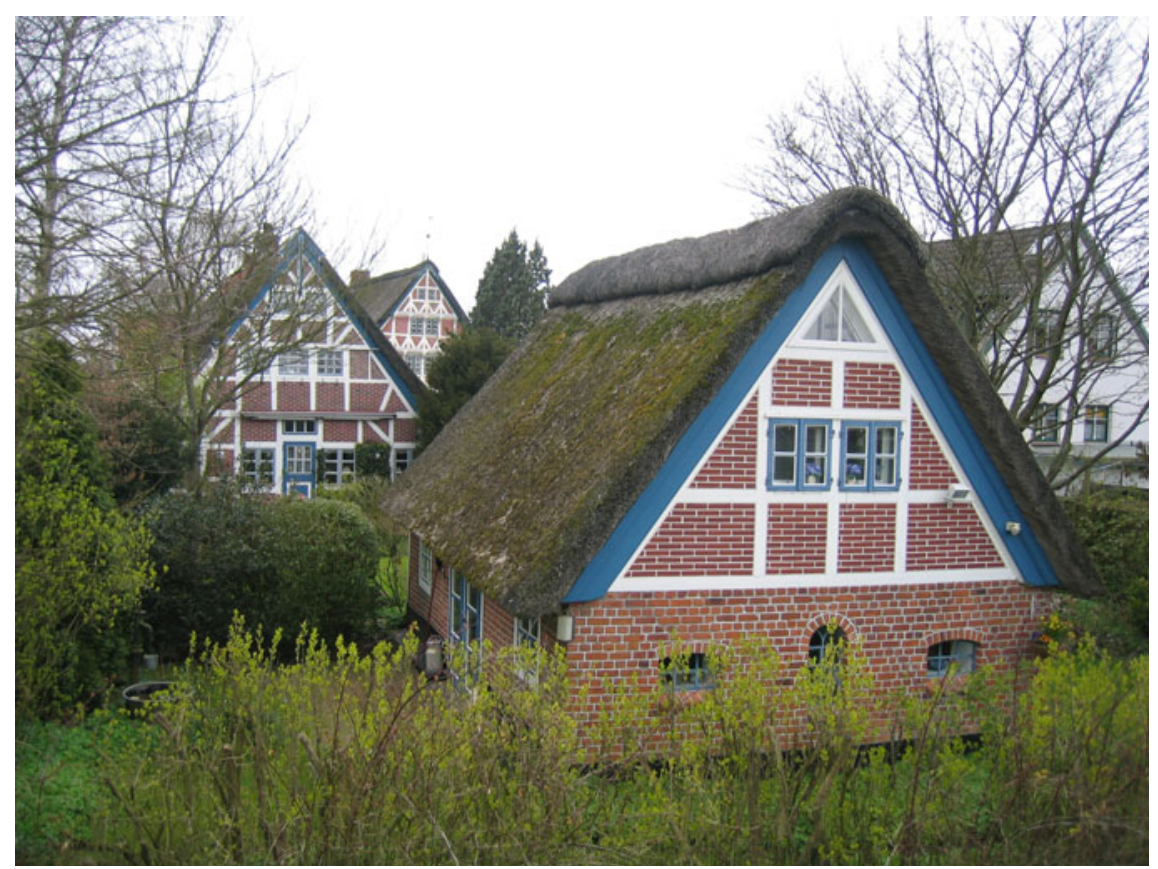

Fig. 8 Traditional Altländer houses possess a high degree of authenticity. Photograph Kruse (2008); released under a Creative Commons Attribution-NonCommercial-NoDerivatives 4.0 International License

In addition, and even more importantly, the Association has become a focal point for local development and protection planning in general. They were a driving force and competence center in developing the Altländer Charta (Samtgemeinde Lühe et al. 2011a), which sets out a central guiding principle (Leitbild, Samtgemeinde Lühe et al. 2011b) for tourism, planning, and economic development for the historical Holler colony heritage of the Altes Land. It sets out guidelines for local people and decision makers on how to engage with the region; it also describes the history, characteristics, and current status of the landscape. Similarly, it published a building guide (Baufibel), focusing on the protection of built heritage (Figs. 8 and 9). Most largely, it sets up a participatory process in which citizens and policymakers came up with a regional development plan, the first for the region. The Centre for Research on Holler colonies, founded in 2012, coordinates further participatory processes, enabling locals to base their positions and arguments based on sound knowledge.

The nomination to World Heritage remains in the air-it was not included in the renewed 2014 German Tentative List but rescheduled with the demand for further specifications. But the Association has achieved many successes. Cooperation with Holler colonies in other European countries is ongoing, and signs are everywhere that awareness of the fact of being a Holler Colony is stimulating regional development. 


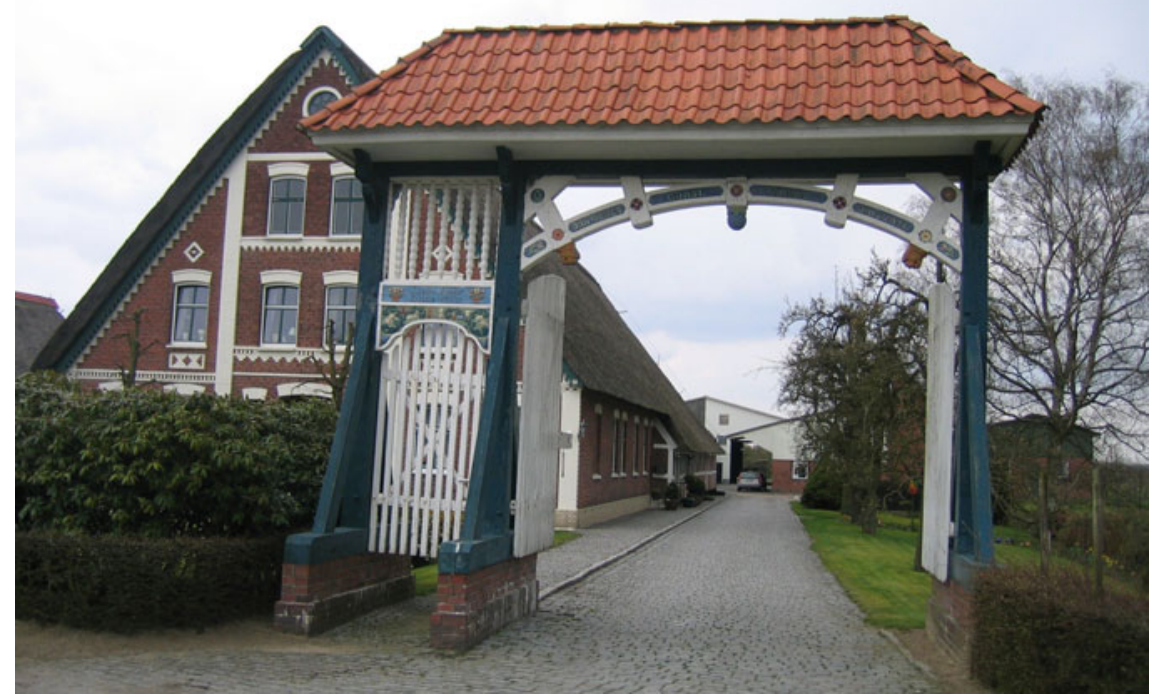

Fig. 9 Typical Altländer Farm, with residence in front, outbuildings and later storage facilities behind. In the foreground is the Brautpforte (bride's door) which the family traditionally only used for either weddings or funerals. The building structure follows the long stripe land clusters. Photograph Kruse (2008); released under a Creative Commons Attribution-NonCommercialNoDerivatives 4.0 International License

In 2016, the Association was recognized at the international level: it was nominated for the European Union Prize for Cultural Heritage/Europa Nostra Awards 2017.

\section{Conclusion}

The Holler colonization produced clear, regional distinctive cultural landscapes across Europe, dominated by the presence of water as a land-shaping factor; in turn, water must be constantly managed in them in order to maintain agricultural space. In the Altes Land, the large-scale container ships that sail down the Elbe to the sea loom in impressive contrast with the small parceled landscape dominated by apple trees. Both, the immaterial heritage of the shaping as well as their ongoing maintenance, make this landscapes a recognizable and unique heritage found all over Europe. Together, they help the people who live in the region to maintain their specific history and identity, and construct a sustainable future.

These elements are of course under pressure from modern-day developments, including the need to keep the rivers navigable and national as well as European 
Union regulation of agriculture. Modern European norms often defy the European past and historical identity, which we need in order to define ourselves. Defining the Holler colonies as cultural heritage may be the only way to safeguard the important ongoing dynamics that created and maintain these unique cultural landscapes.

The Holler colonization is living evidence that migration and cultural exchange can be driving forces in social and economic development. It also shows the resilience of traditional landscape concepts to changes imposed from outside (Janssen et al. 2017). In this respect, the colonies may well be a source of best practices for addressing climate change.

Today, the historical consciousness of the Holler Colonies landscape is growing. More and more locals in Altes Land, including farmers, understand the significance and also the market value of keeping the historic ensembles intact. This awareness does not stop at the maintenance of houses and farms but includes also the fields and ditches as well as traditions and techniques. In line with its European past, this common heritage will be made accessible more widely as part of the Hollerweg, a European cycling route that will start in the Altes Land and connect different Holler Colonies in Poland and the Netherlands. The Hollerweg itself will be part of the Cultural Route program of the Council of Europe (Council of Europe 1987). Awareness of the historic importance of the Altes Land offers the Europeans the opportunity to not only build on heritage and to find new responses to development pressures but also to secure legal protection for the cultural and physical landscape (Hofmeister 2009).

\section{References}

Bartlett R (1993) The making of Europe: conquest, colonization and cultural change 950-1350. Princeton University Press, Princeton

Chodyla Z (2005) The Dutch contribution to the development of the hydraulic system and cultural landscape in Poland, 1547-1945. In: Danner HS et al (eds) Polder pioneers. Netherlands Geographical Studies, pp 33-55

Council of Europe (1987) Cultural routes. https://www.coe.int/en/web/cultural-routes

European Commission (2000a) Water framework directive-framework for Community action in the field of water policy. Directive 2000/60/EC

European Commission (2000b) Natura 2000. http://ec.europa.eu/environment/nature/natura2000/ index_en.htm

European Commission (2018) EIP-AGRI, Inspirational ideas: organic and "conventional" farmers joining forces for innovation. https://ec.europa.eu/eip/agriculture/en/news/inspirational-ideasorganic-and-\%E2\%80\%9Cconventional\%E2\%80\%9D. Date of access: 2018/03/18

Hofmeister AE $(1979,1981)$ Settlement and constitution of the Stade Elb Marsh in the Middle Ages". Volume I: The Stade Elb Marsh before the colonisation in the 12th century. Publication of the institute for Historical Land Research University Göttingen, Hildesheim 1979 [in German], ISBN 3-7848-3642-9, Volume II: The holler colonisation and the land community Kehdingen and Altes Land, Publication of the institute for Historical Land Research University Göttingen, Hildesheim 1981, ISBN 3-7848-3644-5 [in German] 
Hofmeister AE (2009) Holländersiedlungen im Alten Land - Gedanken zu den Hollerkolonien. Speech on the occasion of the inauguration of the Competence centre Hollerkolonies 2009/06/25, Jork (in German)

Janssen J, Luiten E, Renes H, Stegmeijer E (2017) Heritage as sector, factor and vector: conceptualizing the shifting relationship between heritage management and spatial planning. Eur Plan Stud. https://doi.org/10.1080/09654313.2017.1329410

Kaup M (2005) Niederländer in Norddeutschland, vor allem Brandenburg. In: Danner HS et al (eds) Polder pioneers. Netherlands Geographical Studies, pp 57-76

Kompetenzzentrum Ökolandbau Niedersachsen GmbH (2017) Öko-Flächenanteile in den niedersächsischen Landkreisen. http://www.oeko-komp.de/wp/angebot-statistiken-analysenmarktberichte/. Visited: 24/10/2017

Lebecq S (1979) De la protohistoire au Haut Moyen Âge : le paysage des "terpen" le long des côtes de la mer du Nord, spécialement dans l'ancienne Frise. In: Actes des congrès de la Société des historiens médiévistes de l'enseignement supérieur public. 10e congrès, Lille, 1979, pp 125-151. https://doi.org/10.3406/shmes.1979.1331

Lewndowski W, Szewczyk R (2008) Poland—disappearing landscapes. Sport I Turysyka, Muza SA, Warsaw

Raap E (2010) Oproep aan inwoners van Woubrugge en omgeving! Article on "Gemeentepagina Kaag en Braasem" of the local paper. http://witteweekbladkaagenbraassem.nl/ [archive 2010, not available anymore]

Renes H, Piastra S (2011) Polders and politics: new agricultural landscapes in Italian and Dutch Wetlands, 1920s to 1950s. In: Landscapes I, pp 24-41

Renes H (2010) European agricultural landscape history. In: Pungetti G, Kruse A (eds) European culture expressed in agricultural landscapes-the Eucaland project book. Palombi Editori, Roma, $224 \mathrm{p}$

Renes H (2005) Water management and cultural landscape in The Netherlands. In: Danner HS et al (eds) Polder pioneers. Netherlands Geographical Studies, pp 13-32

Samtgemeinde Lühe (2017) Landscape plan - continuation, 1. Draft, Nov 2017. Lühe (in German) Samtgemeinde Lühe et al (2011a) Building code (Baufibel) Altes Land. Hamburg (in German)

Samtgemeinde Lühe et al (2011b) Altländer Charta: Gemeinsames Leitbild für die Kulturlandschaft Altes Land. Lühe (in German)

Stenak M (2005) Dutch influence on Danish Water management - with particular respect to Lammefjorden. In: Danner HS et al (eds) Polder pioneers. Netherlands Geographical Studies, pp $77-101$

Toussaint B (2005) The Dutch-Flemish role in reclamation projects in France. In: Danner HS et al (eds) Polder pioneers. Netherlands Geographical Studies, pp 121-149

Van der Linden, Hendrik (2000) Die Königsrute. Eine Revision der „Cope-Untersuchung“ bezüglich der mittelalterlichen Kultivierungssystematik. Siedlungsforschung 18(S):269-296.

Van Veen J (1955): Dredge_drain — reclaim; The art of a nation, 1st ed (1948). Nijhoff, The Hague

Verein zur Anerkennung des Alten Landes zum Welterbe der UNESCO e.V., Jork (2009) Das Alte Land - einzig, nicht artig. Jork (in German). http://welterbe-altes-land.de/en/ (in English) date of access: $2018 / 03 / 18$

Williamson T (2005) Dutch engineers and the draining of the Fens in Eastern England. In: Danner HS et al (eds) Polder pioneers. Netherlands Geographical Studies, pp 103-119

\section{Links}

http://holland.org.pl/art.php?kat=obiekt\&id=486\&lang=en. Catalogue of monuments of Dutch colonization in Poland 
https://de.wikipedia.org/wiki/Kujawien [16/06/2017]. Wikipedia entry about the region Kujawien in Poland

\begin{abstract}
Alexandra Kruse studied agriculture, landscape development, nature protection and geology in Kiel, Germany. She is the director of insitu World Heritage consulting and secretary general of the Institute for Research on European Agricultural Landscapes e.V. (EUCALAND) (https://eucaland. net), a German nonprofit association which is compiling a database of European agricultural landscapes (https://www.feal-future.org/eatlas/en). Her projects also address UNESCO World Heritage and the revitalization of rural areas.
\end{abstract}

Bernd Paulowitz a historian and political scientist, is World Heritage Coordinator at the Department for Heritage Preservation in Hamburg and World Heritage Manager of the WH-Site "Speicherstadt and Kontorhaus District with Chilehaus". He has been a consultant in cultural heritage for UNESCO and CEO of insitu World Heritage consulting.

Open Access This chapter is licensed under the terms of the Creative Commons AttributionNonCommercial-NoDerivatives 4.0 International License (http://creativecommons.org/licenses/bync-nd/4.0/), which permits any noncommercial use, sharing, distribution and reproduction in any medium or format, as long as you give appropriate credit to the original author(s) and the source, provide a link to the Creative Commons license and indicate if you modified the licensed material. You do not have permission under this license to share adapted material derived from this chapter or parts of it.

The images or other third party material in this chapter are included in the chapter's Creative Commons license, unless indicated otherwise in a credit line to the material. If material is not included in the chapter's Creative Commons license and your intended use is not permitted by statutory regulation or exceeds the permitted use, you will need to obtain permission directly from the copyright holder.

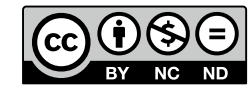

